\title{
PELATIHAN SISTEM BERCOCOK TANAM HIDROPONIK DAN PENGOLAHAN LIMBAH MENJADI PRODUK DAUR ULANG YANG BERMANFAAT DI DESA BARENGKOK TANGERANG
}

\author{
Wahyu Irawati ${ }^{1}$, Grace Charity Mary Cartir ${ }^{2}$, Georgine Gladis Paula Sulardi ${ }^{3}$ \\ 1,2,3 Program Studi Pendidikan Biologi, Fakultas Ilmu Pendidikan, Universitas Pelita Harapan \\ wahyu.irawati@uph.edu, mary.charitygrace@gmail.com, georginegladis24@gmail.com
}

\begin{abstract}
Abstrak
Pengabdian kepada Masyarakat (PkM) merupakan salah satu sarana untuk menjalankan misi Universitas Pelita Harapan yaitu berkontribusi pada kemajuan ilmu pengetahuan dan kebudayaan yang dipimpin oleh wawasan dunia Kristen alkitabiah serta berpartisipasi secara redemtif dalam pengembangan individu dan masyarakat bagi kemuliaan Allah. Kegiatan PkM dilaksanakan di Desa Barengkok, Kabupaten Bogor, Jawa Barat, Indonesia. Analisis situasi menunjukkan bahwa Desa Barengkok tidak memiliki sumber daya manusia yang memahami cara penanganan sampah dan cara bercocok tanam hidroponik yang benar. Mereka terbiasa "memusnahkan" sampah dengan cara dibakar sehingga menyebabkan terjadinya pencemaran udara dan tanah. Tujuan PkM adalah agar penduduk: (1) dapat mengaplikasikan penanaman hidroponik, (2) dapat membedakan jenis-jenis sampah dan mendaur ulang sampah untuk menghasilkan produk yang bermanfaat. Metode PkM yang digunakan adalah metode ceramah dan pelatihan yang pelaksanaannya dibantu oleh mahasiswa Student Life Universitas Pelita Harapan. Kegiatan PkM dilaksanakan pada hari Sabtu, 10 November 2018, pukul 10.00-13.00 WIB yang dihadiri oleh 34 orang peserta. Warga dibagi ke dalam tiga kelompok yaitu: 1) kelompok hidroponik; 2) kelompok daur ulang sampah plastik; dan 3) kelompok daur ulang sampah kertas. Kegiatan PkM menghasilkan pemahaman warga akan pentingnya mendaur ulang sampah, dapat mempraktekkan cara pembuatan produk daur ulang yang bermanfaat serta cara bercocok tanam hidroponik.
\end{abstract}

Kata Kunci : Desa Barengkok, daur ulang, hidroponik, sampah.

\section{PENDAHULUAN}

Allah menciptakan alam semesta serta isinya dengan sangat baik dan teratur. Makhluk hidup dan benda mati mengisi alam semesta dan menempati suatu lingkungan tertentu. Lingkungan mencakup sumber daya alam dan interaksi antara makhluk hidup maupun benda mati. Manusia yang diciptakan Allah diberikan mandat untuk mengelola setiap sumber daya yang ada. Akan tetapi, karena kejatuhan manusia dalam dosa, sehingga manusia tidak mampu menjaga dan mengelola lingkungan dengan baik. Masalah tentang lingkungan mulai bermunculan seperti tindakan membuang sampah secara sembarangan.

Darmasetiawan (2004) mengatakan, menurut karakteristiknya, limbah terdiri dari limbah cair, limbah gas/partikel, limbah padat dan limbah B3 (Bahan Berbahaya dan Beracun). Limbah padat adalah hasil buangan berupa padatan dan lumpur yang berasal dari proses pengolahan serta dapat berasal dari kegiatan industri dan juga domestik. 
Limbah padat merupakan limbah yang paling banyak terdapat dalam lingkungan. Dalam keseharian, limbah padat lebih dikenal dengan istilah sampah. Sampah dapat menjadi masalah sosial karena berpotensi menimbulkan pencemaran lingkungan (tanah dan air) dan berbahaya ketika terjadi banjir dan air pasang laut. Akumulasi dari persoalan ini akan mengakibatkan rendahnya kesehatan masyarakat.

Sampah merupakan produk samping dari aktivitas manusia sehari-hari yang apabila tidak dikelola dengan baik akan mengakibatkan tumpukan yang semakin banyak. UU 18 tahun 2008 tentang pengelolaan sampah mendefinisikan sampah sebagai sisa kegiatan sehari-hari manusia dan/atau proses alam yang berbentuk padat. Selain itu, sampah juga diartikan sebagai semua buangan yang timbul akibat aktivitas manusia dan hewan yang biasanya berbentuk padat yang dibuang karena tidak dibutuhkan atau tidak diinginkan lagi (Tchobanoglous, 1993).

Produksi sampah yang tinggi bila tidak disertai dengan pengelolaan yang baik akan menimbulkan pencemaran. Sampah, khususnya sampah plastik, sangat berpotensi menimbulkan gangguan lingkungan baik berupa pencemaran air, tanah dan udara serta gangguan kesehatan dan sosial ekonomi karena sifatnya yang tidak bisa terurai. Maka, perlu kerja sama dari semua pihak untuk menanggulangi masalah sampah. Maka dari itu, penanganan sampah perlu didukung sarana dan prasarana yang memadai terutama untuk daerahdaerah terpencil atau pinggiran kota yang kurang menjadi perhatian pemerintah pusat.

Masalah lingkungan yang lain adalah sumber daya alam, seperti tanah yang tidak subur sehingga sulit dimanfaatkan oleh manusia. Untuk mengatasi masalah tersebut terdapat satu metode bercocok tanam yang baik yaitu hidroponik. Hidroponik merupakan salah satu inovasi baru dalam dunia pertanian yang metodenya telah banyak diterapkan. Hidroponik adalah metode menanam dengan pemanfaatan air dan tanpa penggunaan tanah sebagai media tanam (Tallei, E. Trina et al., 2017).

Sistem penanaman hidroponik banyak digemari orang karena kepraktisannya. Hidroponik hanya mengandalkan air sebagai nutrisi tanaman dan tidak menggunakan tanah sebagai media tanam. Metode ini sangat memudahkan orang-orang yang ingin bercocok tanam, namun tidak mempunyai lahan yang luas dan subur.

Berdasarkan masalah-masalah tersebut, perlu adanya solusi yang tepat yang harus dilakukan, yaitu melalui daur ulang sampah dan juga sistem penanaman hidroponik. Manfaat dari pelatihan daur ulang sampah dan hidroponik ialah untuk mengatasi masalah lingkungan yang terjadi pada suatu daerah. Masalah tersebut seperti penimbunan sampah rumah tangga dan minimnya lahan pada suatu daerah untuk bercocok tanam. Selain untuk mengatasi masalah lingkungan yang terjadi, daur ulang sampah juga menjadi salah satu cara bagi warga untuk membuat suatu barang yang berguna yang dapat dipakai dan dijual. Sedangkan, dengan sistem penanaman hidroponik, manfaat yang didapatkan oleh warga adalah dapat bercocok tanam dengan mudah tanpa perlu memikirkan lahan yang luas, selain itu, warga juga dapat memperoleh hasil dari sistem hidroponik yang dapat dikonsumsi maupun dijual.

Salah satu daerah yang perlu didukung dan diedukasi mengenai masalah-masalah diatas adalah Desa Barengkok, sebuah desa terpencil yang terletak di perbatasan kota Bogor dan Serang, Banten. Hasil observasi ke Desa Barengkok menunjukkan bahwa desa tersebut tidak memiliki sarana dan prasarana yang memadai untuk dapat melakukan proses penanganan sampah dan bercocok tanam yang baik. Desa Barengkok juga tidak memiliki sumber daya manusia yang memahami cara penanganan sampah dan bercocok tanam yang baik karena rata-rata pendidikan dan pengetahuan penduduk setempat terbilang masih rendah. Mereka terbiasa "memusnahkan" sampah dengan cara dibakar yang berlanjut pada pencemaran udara dan tanah karena dilakukan secara berulang dan terus-menerus. Kebiasaan membakar sampah ini juga telah mengancam kesehatan penduduk desa, khususnya anak-anak serta terjadinya pencemaran udara dan tanah. Berdasarkan masalah tersebut tujuan dari penulisan makalah ini adalah agar penduduk Desa Barengkok: 1) dapat memahami, menerapkan dan mengaplikasikan penanaman secara hidroponik dengan benar; 2) membedakan jenis-jenis sampah 
dan mendaur ulang sampah tersebut menjadi produk daur ulang yang bermanfaat.

\section{METODE}

Metode kegiatan pengabdian kepada masyarakat $(\mathrm{PkM})$ yang digunakan adalah metode ceramah dan pelatihan yang pelaksanaannya dibantu oleh mahasiswa Student Life Universitas Pelita Harapan. Kegiatan PkM berupa pelatihan tentang sistem bercocok tanam hidroponik dan pengolahan limbah menjadi produk daur ulang yang bermanfaat. Kegiatan PkM dilaksanakan pada hari Sabtu, 10 November 2018, pukul 10.00-13.00 WIB di Desa Barengkok, Tangerang, Indonesia yang dihadiri oleh 34 orang peserta. Pelatihan yang diberikan berbentuk: 1) penyuluhan tentang sistem penanaman sistem hidroponik dan pengolahan limbah sampah; 2) praktek menanam secara hidroponik; dan 3) mendaur ulang limbah sampah.

Kegiatan diawali dengan doa pembukaan yang dibawakan oleh Ibu Wahyu Irawati yang sekaligus berperan sebagai pembicara dalam pelatihan tersebut. Pembicara mengawali pelatihan dengan menyampaikan latar belakang dilaksanakannya PkM. Selanjutnya, pembicara menyampaikan tujuan dilaksanakan pelatihan.

Pelatihan ini dilanjutkan dengan praktek secara langsung mengenai tahap-tahap daur ulang dan hidroponik. Warga dibagi ke dalam tiga kelompok yaitu: 1) kelompok hidroponik; 2) kelompok daur ulang sampah plastik; dan 3) kelompok daur ulang sampah kertas. Mahasiswa dari UPH juga dibagi ke dalam tiga kelompok tersebut untuk menjelaskan tahap-tahap melakukan daur ulang sampah maupun hidroponik, akan tetapi warga juga diberi kesempatan untuk dapat bergabung bersama kelompok lain untuk mendengar dan melihat penjelasan mengenai hidroponik maupun daur ulang sampah.

Pembuatan hidroponik dibagi menjadi 3 tahap yaitu: 1) pembuatan nutrisi; 2) pembuatan media tanam; 3) pembuatan rumah tanam. Nutrisi yang digunakan adalah nutrisi A dan B. Nutrisi A mengandung unsur Kalium dan nutrisi B mengandung unsur Fosfat Sulfat, pembuatan nutrisinya harus dilarutkan dengan air terlebih dahulu (Gambar 1). Pembuatan media tanam menggunakan rockwool karena mudah menyerap air (Gambar 2). Pembuatan media tanam menggunakan botol mineral bekas dan kain flanel. Kain flanel digunakan sebagai sumbu yang untuk menahan media tanam yang akan diletakkan. Pembuatan rumah tanam memerlukan alat dan bahan yang lain karena botol mineral bekas butuh dilubangi dan dipotong terlebih dahulu (Gambar 3).

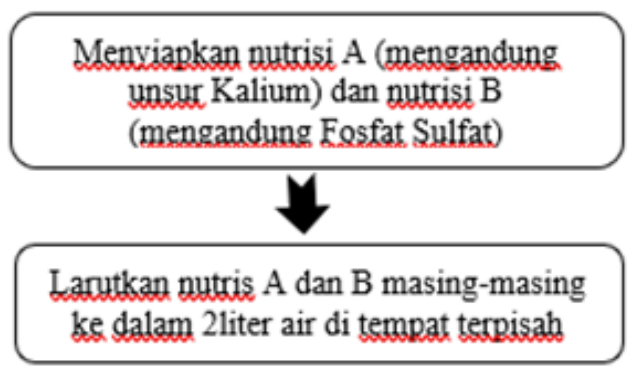

Gambar 1. Tahap 1 pembuatan nutrisi tanaman 


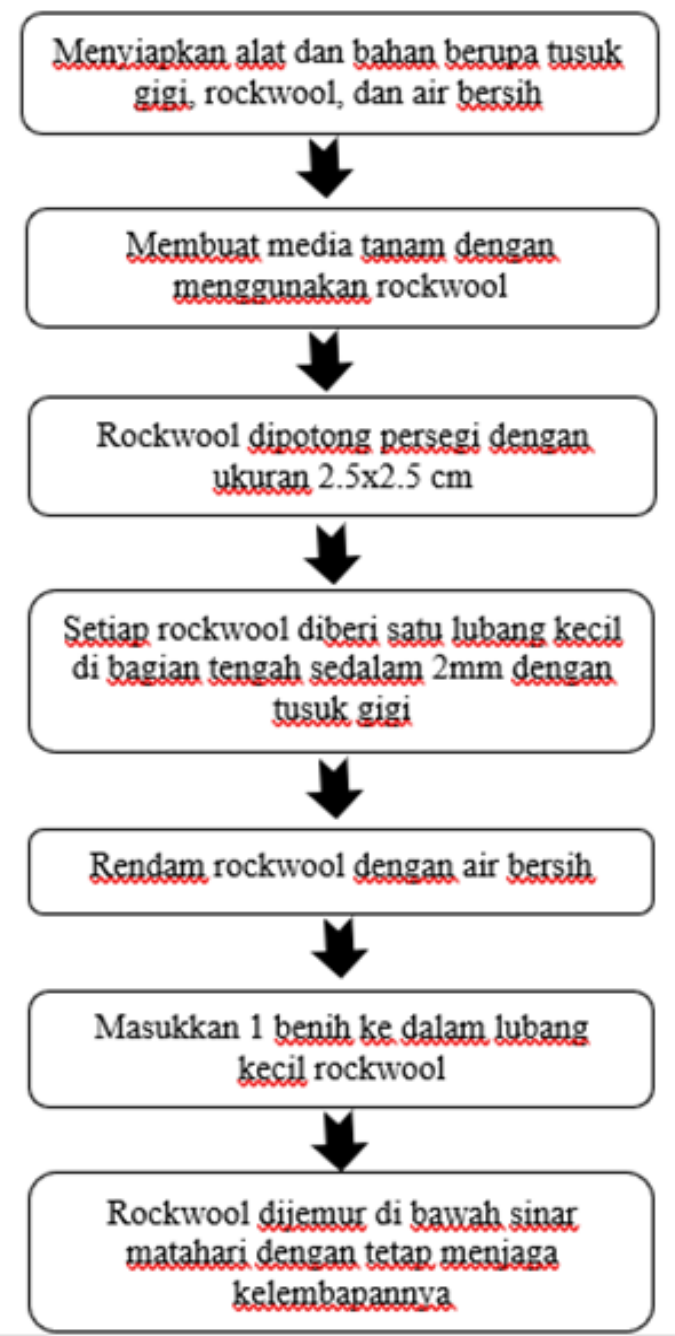

Gambar 2. Tahap 2 pembuatan media tanam

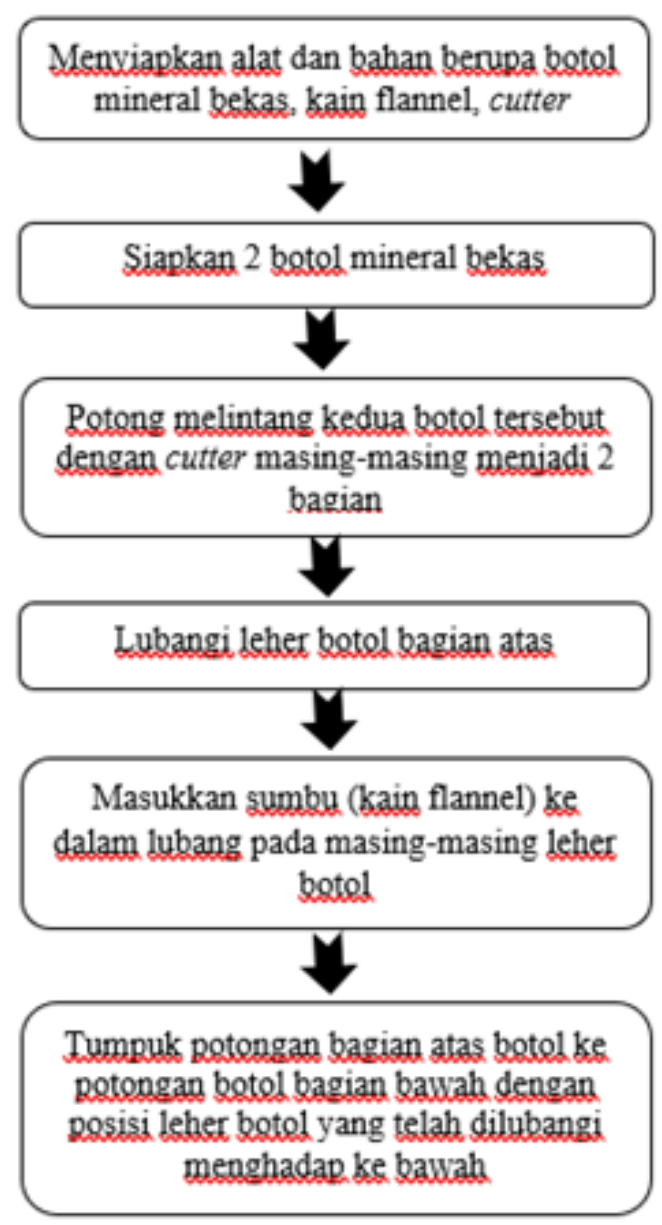

Gambar 3. Tahap 3 pembuatan rumah tanam

Pembuatan daur ulang sampah dibagi menjadi 2 jenis yaitu daur ulang sampah plastik dan daur ulang sampah kertas. Pembuatan daur ulang sampah plastik khususnya sampah kemasan sabun, pewangi, maupun makanan, didaur ulang menjadi barang bermanfaat yaitu tempat pensil (Gambar 4), sedangkan, pembuatan daur ulang sampah kertas khususnya kertas koran didaur ulang menjadi barang bermanfaat seperti keranjang (Gambar 5). Keranjang yang sudah jadi dicat dan dihias dengan menarik agar lebih indah dan bernilai jual tinggi. 


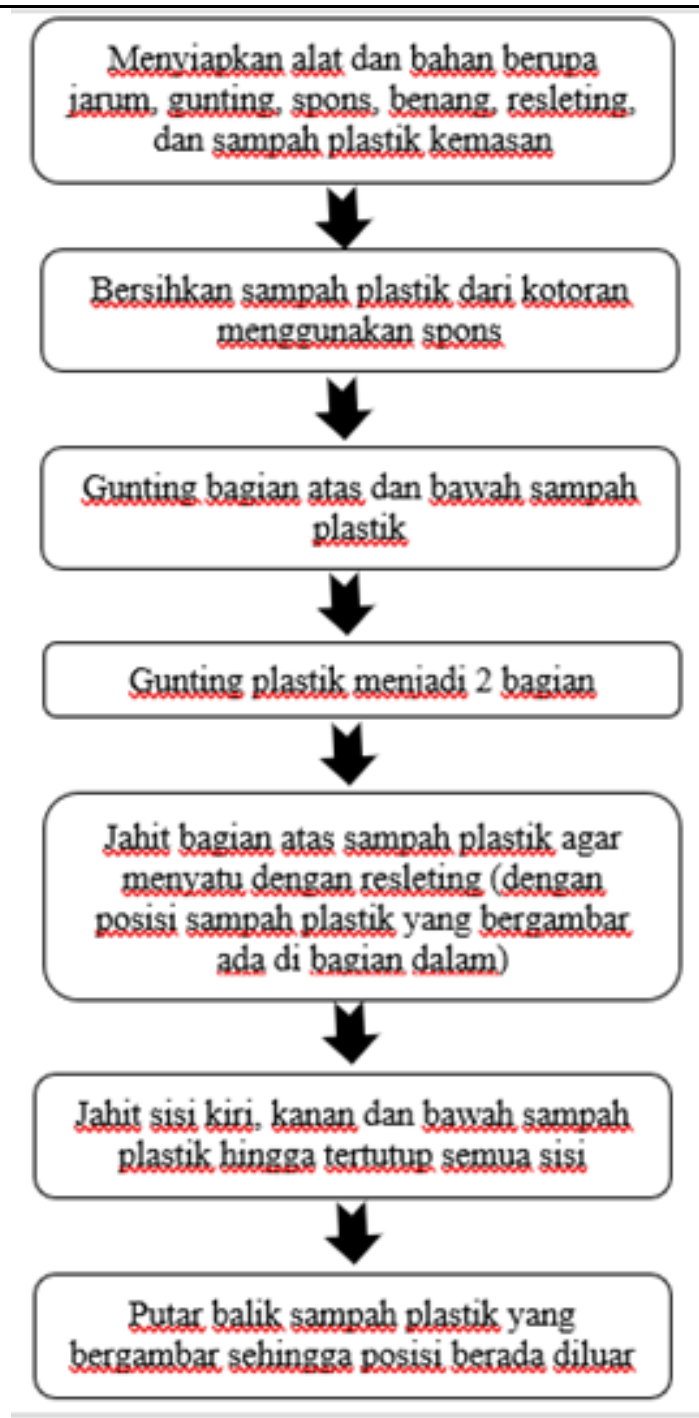

Gambar 4. Tahap pembuatan sampah plastik

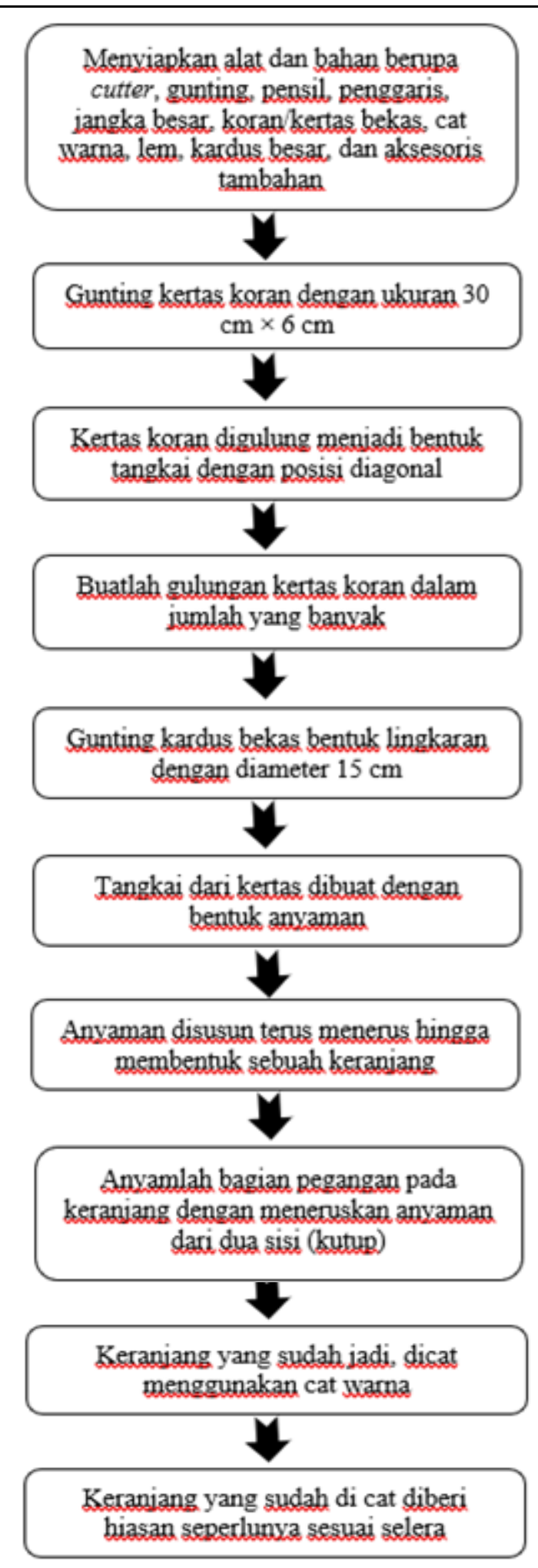


Gambar 5. Tahap pembuatan sampah kertas menjadi keranjang

Pelatihan ini diakhiri dengan pemberian cindera mata dari UPH dan pembicara menyampaikan ucapan terima kasih serta pesan untuk warga agar semakin mencintai lingkungan dengan cara menerapkan pelatihan yang sudah diberikan kemudian ditutup dengan doa. Kegiatan terakhir adalah sesi foto bersama dosen, mahasiswa dan seluruh warga yang hadir dalam pelatihan tersebut.

\section{HASIL DAN PEMBAHASAN}

Kegiatan PkM dilaksanakan pada hari Sabtu, 10 November 2018, pukul 10.00-13.00 WIB di Desa Barengkok, Tangerang, Indonesia. Kegiatan PkM berlangsung selama tiga jam yang dihadiri oleh 34 warga Desa Barengkok. Kegiatan diawali dengan doa pembukaan oleh pembicara dan penyampaian latar belakang dilaksanakannya PkM untuk menjalankan misi Universitas Pelita Harapan, yaitu berkontribusi pada kemajuan ilmu pengetahuan dan kebudayaan yang dipimpin oleh wawasan dunia Kristen yang Alkitabiah serta berpartisipasi secara redemtif dalam pengembangan individu dan masyarakat bagi kemuliaan Allah. Selanjutnya, dilakukan penyampaian tujuan, materi dan terakhir melakukan kegiatan praktik daur ulang serta hidroponik.

Kegiatan PkM yang dilakukan di Desa Barengkok meliputi pelatihan dan penjelasan mengenai bercocok tanam dengan sistem hidroponik dan daur ulang sampah menjadi barang yang bermanfaat. Pelatihan yang diberikan berbentuk ceramah dan penjelasan alat dan bahan yang dibutuhkan serta demonstrasi tahap-tahap pembuatannya mengenai hidroponik dan daur ulang

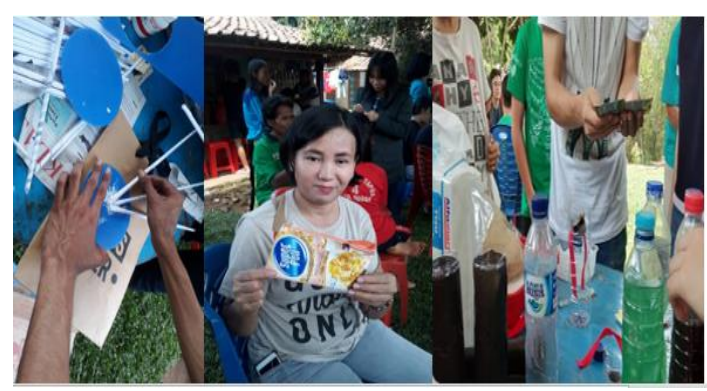

sampah (Gambar 6). Daur ulang sampah dibagi menjadi 2 yaitu sampah kertas dan sampah plastik.

Gambar 6. Bentuk pelatihan kegiatan PkM

Sasaran khusus yang ingin dicapai dari kegiatan pelatihan ini yaitu diharapkan warga Desa Barengkok dapat memahami cara menjaga dan mengelola lingkungan dengan baik sehingga masalah lingkungan yang terjadi dapat diatasi. Sasaran tersebut dibagi menjadi dua bagian penting. Pertama, melalui kegiatan PkM ini diharapkan setiap warga mampu menerapkan dan mengaplikasikan penanaman secara hidroponik dengan benar, sehingga hasil dari sistem bercocok tanam hidroponik ini memiliki hasil yang bagus dan dapat dijadikan sebagai sumber pendapatan yang memadai. Kedua, diharapkan warga juga dapat membedakan jenis-jenis sampah dan mendaur ulang sampah tersebut menjadi produk/barang daur ulang yang bermanfaat seperti tempat pensil dari sampah plastik dan keranjang dari sampah kertas sehingga hasilnya dapat mengurangi masalah pencemaran lingkungan dan dapat dijual.

\section{Hidroponik}

Kegiatan PkM yang dilakukan meliputi pelatihan sistem bercocok tanam hidroponik dan dilanjutkan dengan penjelasan secara langsung mengenai tahap-tahap pembuatan hidroponik. Warga diberikan materi bagaimana cara mengelola lingkungan. Mahasiswa menjelaskan bahwa cara pengelolaan lingkungan bisa juga dengan menerapkan cara bercocok tanam secara hidroponik. Hidroponik merupakan sistem budidaya tanaman yang sederhana dengan pemanfaatan air dan penambahan nutrisi hara tanpa menggunakan tanah sebagai media tanam untuk mendapatkan hasil panen yang cepat (Perwitasari, Tripatmasari, \& Wasonowati, 2012). Bercocok tanam dengan sistem hidroponik jika diterapkan dapat mengatasi kesulitan warga dalam menanam tumbuh-tumbuhan sebagai akibat dari masalah pencemaran lingkungan, khususnya pencemaran tanah. Penjelasan materi mengenai cara bercocok tanam dengan sistem hidroponik, dijelaskan dengan bahasa yang sederhana sehingga dapat dimengerti dan 
diaplikasikan dalam kehidupan sehari-hari oleh warga.

Warga di Desa Barengkok masih belum maksimal dalam bercocok tanam. Tanah dan lahan di Desa Barengkok masih banyak yang belum dapat dimanfaatkan dengan baik. Warga masih belum mampu untuk bertani atau bercocok tanam karena cenderung mendapatkan segala sesuatu dari alam secara cuma-cuma. Pelatihan bercocok tanam dengan sistem hidroponik merupakan solusi yang tepat untuk diterapkan kepada warga Desa Barengkok, karena tidak membutuhkan lahan yang luas dan tidak membutuhkan tanah untuk media pertanaman, selain itu tanaman hidroponik juga lebih sehat dan mudah di kontrol (Amri, Iqbal, \& Alimin, 2017).

Pelatihan bercocok tanam hidroponik dilakukan di dalam kelompok yang sudah dibagi oleh mahasiswa. Setiap mahasiswa di dalam kelompok masing-masing membagikan alat dan bahan yang digunakan dan menjelaskan fungsinya, serta tahaptahap bercocok tanam sistem hidroponik (Gambar 7). Warga yang berada di kelompok hidroponik mendengar penjelasan dan diberi kesempatan untuk melakukan tanya jawab (Gambar 8). Tanya jawab dilakukan untuk memastikan bahwa warga memahami setiap materi yang telah disampaikan. Kegiatan setelah tanya jawab dilanjutkan dengan mahasiswa mendemonstrasikan secara langsung cara bercocok tanam menggunakan sistem hidroponik kepada warga (Gambar 9).

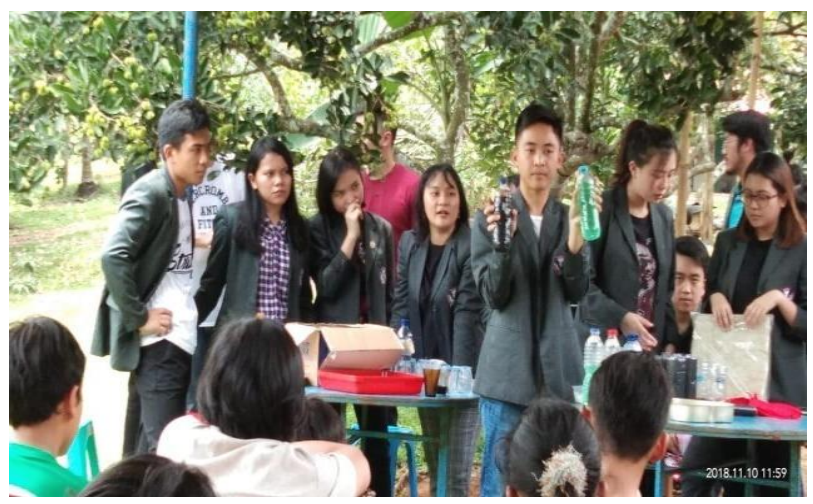

Gambar 7. Pelatihan sistem bercocok tanam hidroponik

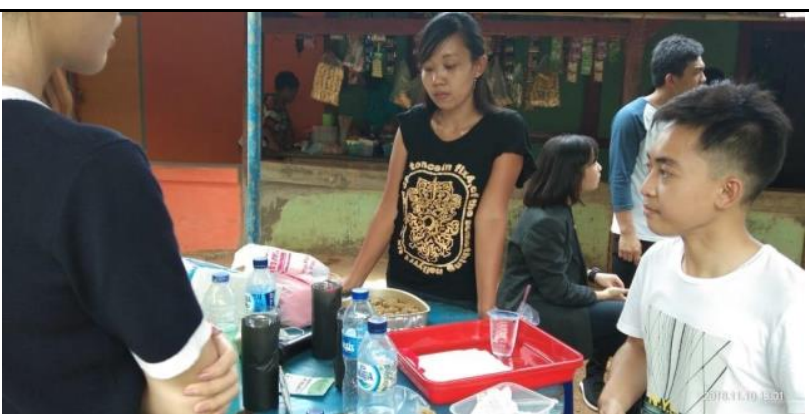

Gambar 8. Tanya jawab warga pada pelatihan sistem bercocok tanam hidroponik

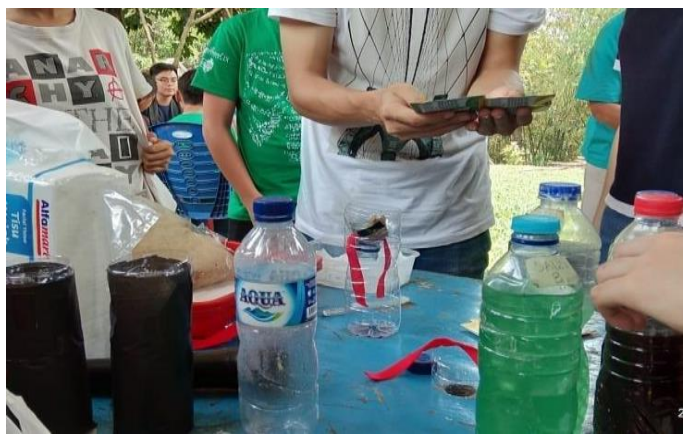

Gambar 9. Demonstrasi cara sistem bercocok tanam hidroponik

Pada sesi demonstrasi cara bercocok tanam dengan sistem hidroponik, alat dan bahan yang digunakan sangat mudah untuk dicari. Wadah yang digunakan sebagai pot atau rumah tanam adalah botol plastik bekas dan kain flanel. Selain mudah dicari, dengan memanfaatkan botol plastik sebagai pot, hal tersebut juga bisa membantu mengurangi sampah plastik yang berserakan di lingkungan. Dalam demonstrasi cara pembuatannya, warga diajarkan materi mengenai media tanam yang digunakan pada sistem bercocok tanam hidroponik adalah rockwool. Rockwool merupakan serabut bebatuan yang dipanaskan sehingga dapat dijadikan media tanam karena steril dari sumber hama, penyakit dan gulma, serta praktis karena mudah menyerap air (Wasliyah, 2019). Menggunakan rockwool sebagai media tanam sangat baik karena rockwool memiliki banyak keunggulan. Tanaman lebih bagus dan tumbuh tinggi pada media tanam rockwool karena rockwool memiliki serabut yang lembut, halus, dan jika disiram banyak air tidak mudah memadat, sehingga akar lebih mudah 
menyerap air ke dalam tanaman (Syawaluddin \& Harahap, 2016).

Bercocok tanam dengan sistem hidroponik sangat mudah dan praktis, namun butuh waktu yang lama untuk prakteknya. Praktek hidroponik membutuhkan waktu yang lama, sehingga mahasiswa hanya menjelaskan dan memberikan alat dan bahan tersebut kepada warga agar dapat dilaksanakan. Melalui demonstrasi secara langsung yang telah dilakukan dihadapan warga diharapkan dapat memberikan gambaran terhadap hasil akhirnya. Hasil akhir dari sistem bercocok tanam hidroponik menggunakan botol plastik bekas sangat sederhana dan mudah untuk dipraktekkan oleh warga Desa Barengkok (Gambar 10).

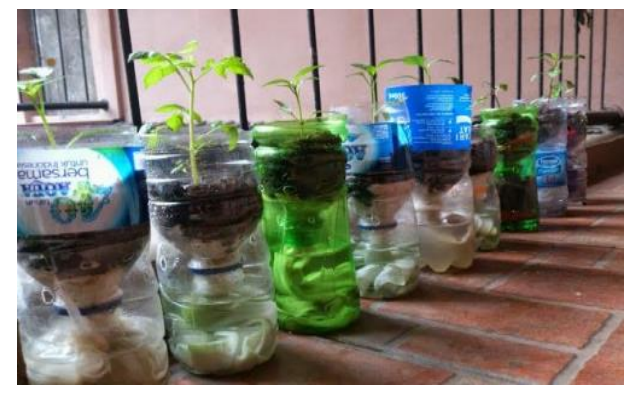

(Amri, Iqbal, \& Alimin, 2017)

Gambar 10. Hasil sistem bercocok tanam hidroponik

Kegiatan PkM mengenai pelatihan tentang penanaman sistem hidroponik serta praktek menanam secara hidroponik diharapkan dapat bermanfaat bagi warga Desa Barengkok. Setelah pelatihan ini diharapkan warga dapat memahami, menerapkan dan mengaplikasikan penanaman secara hidroponik dengan benar. Sistem bercocok tanam hidroponik ini diharapkan dapat menjadi alternatif bagi warga Desa Barengkok yang memiliki lahan yang terbatas dan masalah pencemaran lingkungan seperti pencemaran tanah. Selain itu hasil dari sistem bercocok tanam hidroponik ini dapat dijadikan sebagai sumber pendapatan yang memadai karena hasilnya lebih sehat dan bisa dijual. Sistem bercocok tanam hidroponik ini memiliki beberapa keuntungan, yaitu: 1) Hasil produksi bagus dan lebih tinggi; 2) Keberhasilan lebih terjamin untuk tanaman berproduksi dan tumbuh; 3) Perawatan lebih praktis dan hemat pupuk; 4) Tidak membutuhkan banyak tenaga karena praktis dan tidak menggunakan tanah (Roidah, 2014).

\section{Daur Ulang Sampah}

Warga Desa Barengkok memiliki tingkat
pendidikan yang cukup rendah sehingga mempengaruhi cara berpikir warga setempat, demikian juga kemampuan warga dalam mengelola sampah baik organik maupun non organik. Sampah organik belum dapat diolah sebagai kompos, demikian juga dengan sampah plastik maupun kertas yang menumpuk belum dapat diolah menjadi produk yang bermanfaat. Oleh karena itu, kegiatan PkM lainnya yang dilakukan di Desa Barengkok ialah pelatihan untuk mendaur ulang sampah. Melalui kegiatan PkM ini, warga setempat diberikan pelatihan untuk mendaur ulang sampah, khususnya sampah non organik (Gambar 11). Sampah non organik merupakan sampah yang bersumber dari sisa manusia yang dapat diurai oleh bakteri, namun dengan proses yang sangat lama, bisa sampai beratus-ratus tahun (Latifatul, Afriezal, Auliya, \& Nur, 2018).

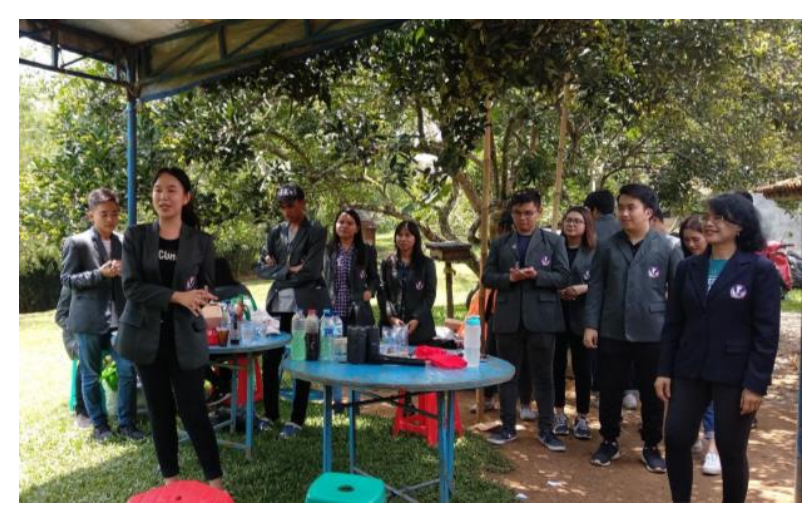

Gambar 11. Pelatihan daur ulang sampah menjadi barang bermanfaat

Daur ulang sampah yang dilakukan meliputi daur ulang sampah kertas dan plastik yang bersumber dari limbah rumah tangga. Sampah kertas maupun plastik yang telah dikumpulkan dibuat menjadi barang yang bernilai dan dapat dijual. Sampah kertas dibuat menjadi keranjang, sedangkan sampah plastik dibuat menjadi tempat pensil. Daur ulang sampah yang dilakukan menjadi salah satu 
solusi yang efektif dalam mengurangi jumlah sampah yang terus meningkat (Setiadi, 2015). Oleh karena itu, daur ulang sampah penting untuk dilakukan.

Hal pertama yang dilakukan adalah menjelaskan tujuan dari daur ulang sampah tersebut, yaitu agar penumpukan sampah semakin berkurang. Sampah yang awalnya terlihat tidak berguna dapat menjadi suatu barang yang berguna dan memiliki nilai jual. Selanjutnya, warga diberikan pelatihan mengenai dampak dari pembuangan sampah yaitu: 1) Membuang sampah sembarangan tanpa mengelolanya dapat menyebabkan terjadinya pencemaran tanah di lingkungan; 2) sampah dapat menjadi masalah sosial karena berpotensi menimbulkan pencemaran lingkungan dan berbahaya ketika terjadi banjir dan air pasang laut; 3) Akumulasi dari persoalan ini akan mengakibatkan rendahnya kesehatan masyarakat.

Warga juga diberikan materi mengenai cara mengatasi dampak pembuangan sampah tersebut yaitu dengan cara daur ulang sampah. Cara daur ulang sampah yang disampaikan meliputi daur ulang sampah kertas dan sampah plastik. Melalui daur ulang sampah kertas dan plastik menghasilkan barang berguna seperti keranjang, tempat pensil dan barang lainnya. Pelatihan daur ulang sampah plastik dan kertas dilakukan di dalam kelompok yang sudah dibagi, ada kelompok yang khusus untuk pelatihan daur ulang sampah plastik dan juga kelompok untuk daur ulang sampah kertas (Gambar 12).

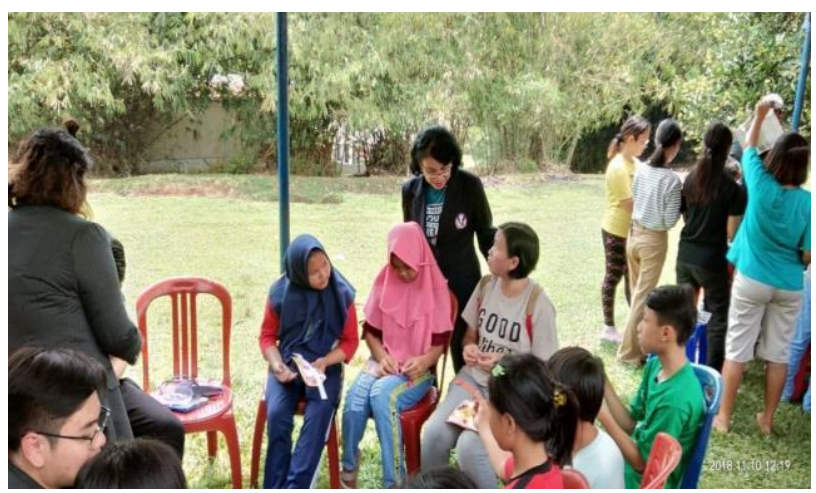

Gambar 12. Penjelasan tujuan daur ulang sampah plastik dan kertas di dalam kelompok

Penjelasan tersebut dijabarkan dengan bahasa yang sederhana sehingga warga Desa
Barengkok dapat memahami dan mengaplikasikannya dalam kehidupan sehari-hari. Setelah penjelasan tersebut, mahasiswa menjelaskan alat dan bahan yang diperlukan untuk mendaur ulang sampah. Alat dan bahan yang dipakai pun sangat mudah didapat dan harganya terjangkau. Misalnya untuk mendaur ulang sampah plastik menjadi tempat pensil, dibutuhkan resleting serta benang dan jarum. Alat dan bahan tersebut tergolong mudah dicari dan harganya sangat ekonomis (Gambar 13). Selain itu, untuk mendaur ulang kertas menjadi keranjang hanya dibutuhkan lem kertas dan gunting, serta cat untuk mewarnai keranjang sehingga lebih menarik (Gambar 14). Setelah tahap penjelasan alat dan bahan, mahasiswa memberikan kesempatan kepada warga untuk bertanya tentang daur ulang tersebut. Setelah itu, mahasiswa langsung mendemonstrasikan bagaimana pengerjaan daur ulang sampah, baik sampah kertas maupun plastik menjadi tempat pensil dan keranjang yang dalam kehidupan sehari-hari dan dapat dijual (Gambar 16).

Hasil akhir dari pelatihan ini adalah warga dapat membuat tempat pensil dari sampah plastik dan juga keranjang dari sampah kertas. Tempat pensil yang dibuat dari sampah plastik berfungsi sangat baik, layaknya tempat pensil pada umumnya, namun tempat pensil yang dibuat dari sampah plastik ini memiliki keunikannya tersendiri, karena baik dari motif maupun warna sudah ada dari sampah plastik itu sendiri, misalnya sampah dari kemasan pewangi lantai (Gambar 17).

Daur ulang yang dilakukan bukan hanya dari sampah plastik namun juga dari sampah kertas. Hasil dari daur ulang ini adalah keranjang yang dibuat berdasarkan bentuk dan warna yang diinginkan. Keranjang yang dibuat tergolong barang yang unik, berguna dan memiliki nilai jual (Gambar 18). Kegiatan PkM diakhiri pukul 12.00 dengan makan siang dan foto bersama (Gambar 19). 


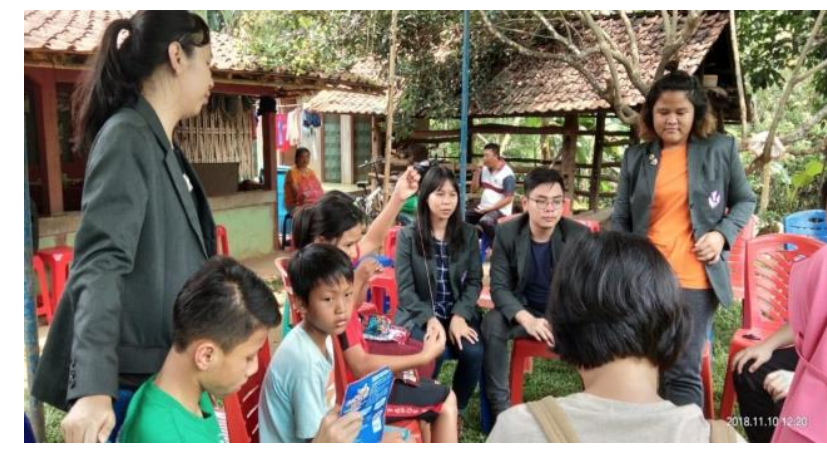

Gambar 13. Penjelasan alat, bahan, tanya jawab, dan demonstrasi daur ulang sampah plastik

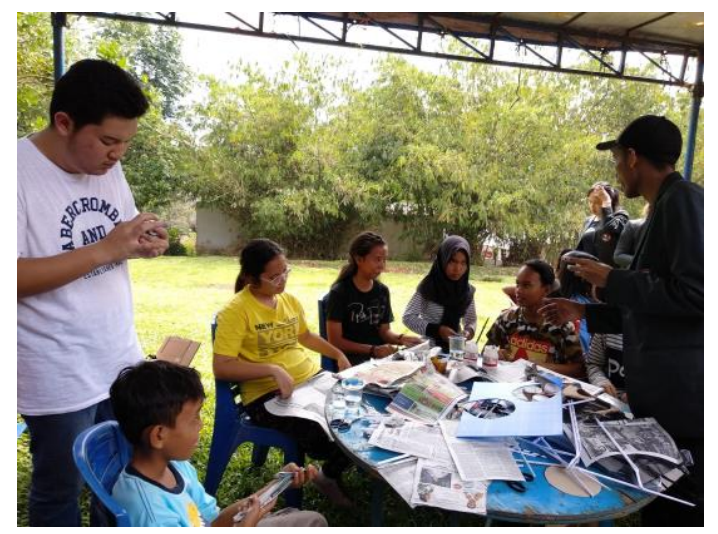

Gambar 14. Penjelasan alat, bahan, tanya jawab, dan demonstrasi daur ulang sampah kertas

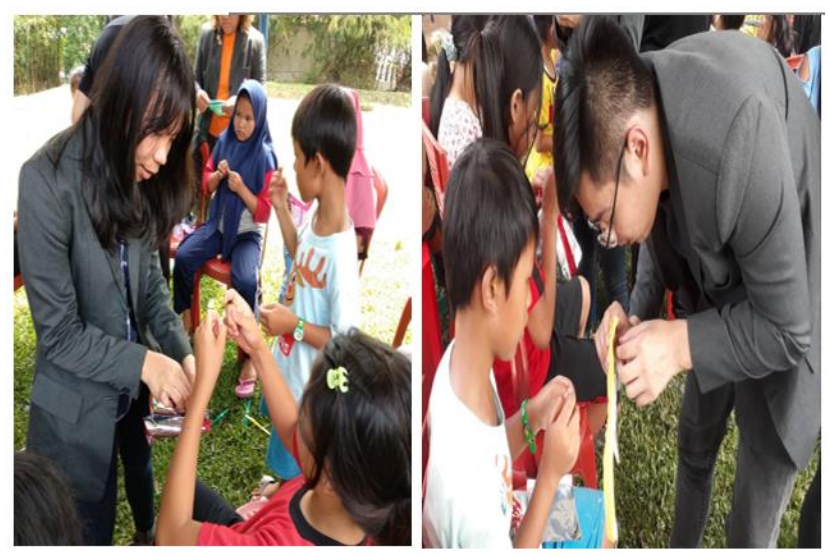

Gambar 16. Praktek langsung pembuatan daur ulang sampah plastik menjadi tempat pensil

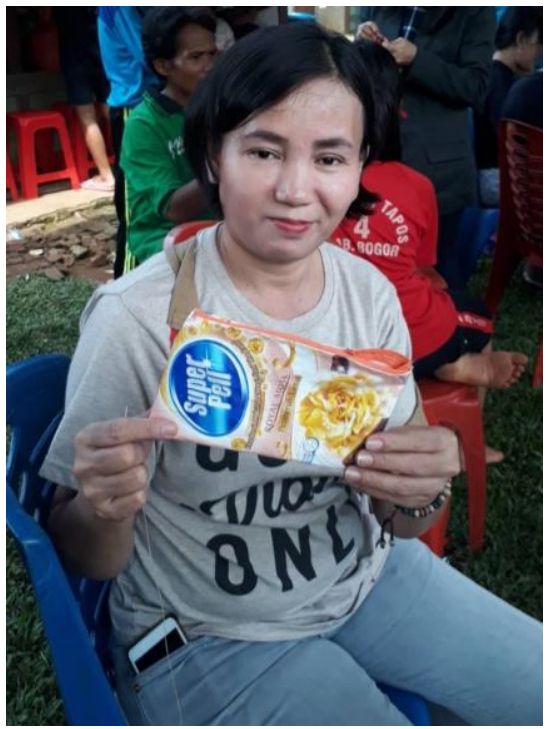

Gambar 17. Hasil akhir daur ulang sampah plastik menjadi tempat pensil

Kegiatan PkM sistem daur ulang sampah dan juga bercocok tanam secara hidroponik memiliki potensi keberlanjutan. Keberlanjutan program ini dilakukan melalui kerjasama antara dosen mahasiswa dan warga dengan harapan program ini dapat terus diterapkan oleh warga sendiri dengan bekal pengetahuan dan praktik yang sudah dilakukan saat pelatihan berlangsung. Pada akhir pelatihan warga diberikan alat dan bahan untuk melakukan daur ulang sampah dan bercocok tanam hidroponik. Oleh sebab itu, warga dapat menerapkan tahap-tahap daur ulang sampah dan hidroponik sesuai dengan praktik yang sudah dilakukan. Alat dan bahan yang diperlukan untuk melakukan daur ulang sampah maupun hidroponik juga mudah didapatkan dan dibeli dengan harga terjangkau, sehingga kedepannya, warga dapat dengan mudah melakukan daur ulang sampah dan hidroponik.

\section{Evaluasi Hasil dan Dampak}

Kegiatan PkM menghasilkan pemahaman warga akan pentingnya mendaur ulang sampah, dapat mempraktekkan cara pembuatan produk daur 
ulang yang bermanfaat serta cara bercocok tanam hidroponik. Pelatihan seperti ini harus sering dilakukan di Desa Barengkok dan menjadi prioritas untuk kedepannya bagi generasi selanjutnya. Pelatihan ini berdampak baik bagi warga Desa Barengkok. Dampak dari pelatihan kegiatan PkM ini yaitu: 1) warga dapat menyadari bahwa pengelolaan sampah dan bercocok tanam merupakan hal yang penting bagi kehidupan warga itu sendiri; 2) warga mendapat pengetahuan mengenai cara menerapkan, mengaplikasikan penanaman secara hidroponik dengan benar; 3) warga mendapat pengalaman baru dalam mengelola lingkungan dengan praktik bercocok tanam sistem hidroponik dan mengelola sampah menjadi tempat pensil dan keranjang yang berkualitas; 4) warga dapat membedakan jenis-jenis sampah dan mengelola sampah tersebut menjadi barang yang bermanfaat serta dapat digunakan atau dijual. Oleh sebab itu, melalui pelatihan ini diharapkan setiap warga tidak hanya menikmati hasil tetapi juga dapat menikmati setiap prosesnya.

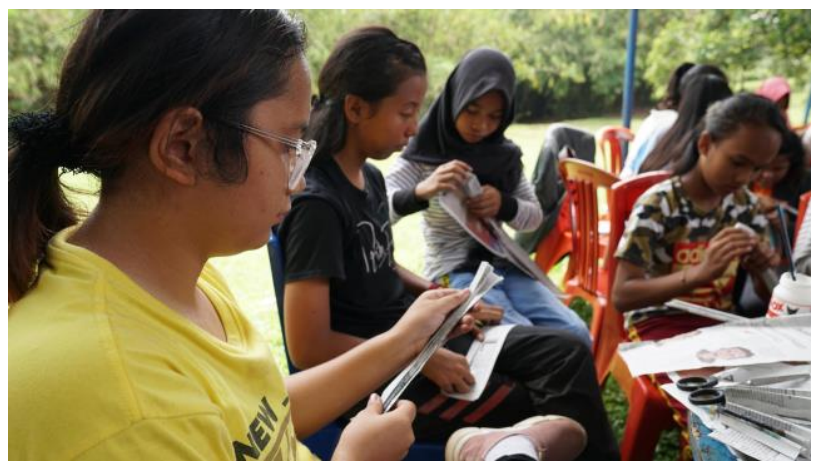

Gambar 18. Praktek langsung pembuatan daur ulang sampah kertas menjadi keranjang

Evaluasi dari pelatihan ini yaitu mengenai keterbatasan waktu dalam melakukan praktek bersama dengan warga. Kurangnya waktu dalam melakukan praktek bersama warga sehingga warga belum sempat melakukan praktek secara langsung menanam dengan sistem hidroponik dan membuat keranjang dari sampah. Hal yang perlu diperhatikan untuk memajukan warga setempat yaitu warga Desa Barengkok juga memerlukan mentor dan partner. Warga sangat senang ketika diberikan pelatihan di dalam sebuah kelompok-kelompok karena setiap mahasiswa yang menjelaskan juga membimbing warga dengan mengajarkan warga dalam praktik pembuatannya.

\section{KESIMPULAN}

Kesimpulan dari pelatihan ini adalah bahwa Allah menciptakan lingkungan yang teratur dan kompleks. Kejatuhan manusia ke dalam dosa mengakibatkan ketidaktaatan manusia sehingga menimbulkan kerusakan lingkungan. Allah melakukan pemeliharaan dengan memberikan hikmat kepada manusia untuk menemukan cara mendaur ulang sampah dan metode hidroponik.

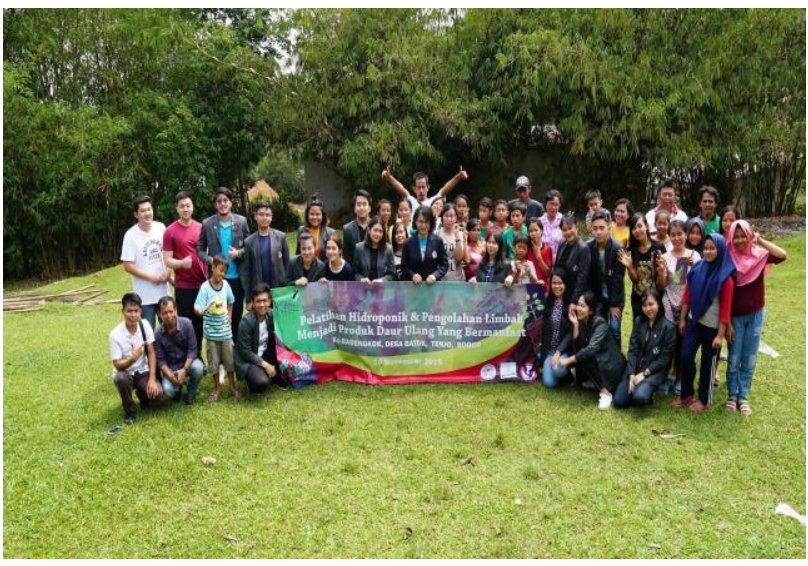

Gambar 19. Foto bersama warga

Melalui kegiatan PkM ini, warga mengetahui bahwa hidroponik adalah metode penanaman dengan pemanfaatan air tanpa menggunakan tanah sebagai media tanam yang dapat diterapkan di rumah. Warga mengetahui bahwa alat dan bahan yang digunakan adalah cutter, gunting, tusuk gigi, wadah transparan, rockwool, nutrisi air bersih, kantong plastik hitam, botol plastik, kain flanel, dan tumbuhan. Warga dapat mempraktekkan langkah-langkah hidroponik yaitu, membuat media tanam, membuat rumah tanam, membuat nutrisi dan membuat pestisida nabati. Warga mempunyai keinginan untuk mempraktekkannya di rumah masing-masing untuk memanfaatkan lahan yang masih ada di sekitar rumahnya.

Warga mengetahui bahwa daur ulang sampah kertas dan plastik adalah cara untuk mengurangi volume sampah di lingkungan dengan 
mengolahnya menjadi barang berguna dan bernilai jual. Warga mengetahui bahwa alat dan bahan yang digunakan yaitu, jarum, gunting, spons, benang, lem, sampah plastik, cutter, pensil, penggaris, jangka besar, kertas bekas, cat warna, lem, kardus bekas, aksesoris tambahan. Warga dapat mempraktekkan langkah-langkah daur ulang yaitu, menyiapkan alat dan bahan dan membuat barang daur ulang sesuai dengan alat dan bahan yang ada. Melalui kegiatan PkM ini warga menyadari untuk tidak membuang sampah plastik dan kertas namun memanfaatkannya menjadi produk yang bermanfaat.

Saran yang dapat diberikan kepada warga di Desa Barengkok berdasarkan pelatihan sistem daur ulang sampah dan hidroponik adalah warga dapat menerapkan sistem daur ulang sampah dan hidroponik berdasarkan tahap-tahap yang sudah diberikan, akan tetapi penerapan sistem daur ulang dan hidroponik tersebut dapat dikembangkan lebih lagi oleh warga dengan kreatif dan inovatif. Contohnya dengan menambah variasi jenis bibit tanaman sayur untuk bercocok tanam secara hidroponik. Warga juga dapat membuat barang yang berbeda dari daur ulang sampah plastik dan kertas, misalnya membuat tas dari sampah plastik atau membuat tirai dari sampah kertas. Penerapan sistem ini akan mengurangi masalah lingkungan yang terjadi serta membuat warga menjadi lebih kreatif dalam mengelola sampah maupun dalam bercocok tanam dengan hidroponik.

\section{UCAPAN TERIMAKASIH}

Ucapan terimakasih disampaikan kepada Lembaga Penelitian dan Pengabdian Masyarakat Universitas Pelita Harapan yang telah memberikan ijin dilaksanakannya kegiatan ini dengan No: PkM: PM-079-M/FIP/XI/2018. Kegiatan ini dapat terlaksana berkat bantuan Henay Hery Rumamite, Aldy Pelleng, Andre Torang, Desniwita Linia Zebua, Yuliastria Sidauruk, yang tergabung dalam Himpunan mahasiswa Program Studi Biologi, Universitas Pelita Harapan. Terimakasih juga diberikan kepada Student Life Universitas Pelita Harapan yang ikut membantu pelaksanaan PkM, yaitu: Sinta Irnia Bela, Sebastian Ryan, Marcelino
Arby, Febiola Efriani, Kevin Tandiono, Jason Nathanael Winarto, Muhammad Ghazian Karami, Matthew Santoso, Vivian Mesia, Anggari Candratia, dan Shannita Valerie Mayasavira.

\section{REFERENSI}

Amri, Iqbal, A. M., \& Alimin. (2017). IbM bercocok tanam secara hidroponik warga RT $05 \mathrm{RW}$ 03 kelurahan Paccerakang kecamatan Makassar. Prosiding Seminar Hasil Pengabdian Kepada Masyarakat (SNP2M), 479-482.

Darmasetiawan. M. (2004). Sampah dan sistem pengelolaannya. Jakarta: Ekamitra Engineering.

Latifatul, F. N., Afriezal, Auliya, \& Nur, K. R. (2018). Pengaruh sosialisasi pemilahan sampah organik dan non organik serta manajemen sampah terhadap penurunan voume sampah di Dusun Krajan Kemuningsari Lor Kecamatan Panti Kabupaten Jember . THE INDONESIAN JOURNAL OF HEALTH SCIENCE , 84-87.

Perwitasari, B., Tripatmasari, M., \& Wasonowati, C. (2012). Pengaruh media tanam dan nutrisi terhadap pertumbuhan dan hasil tanaman pakchoi (Brassica juncea L.) dengan sistem hidroponik. Agrovigor, 5(1), 14-24.

Roidah, I. S. (2014). Pemanfaatan lahan dengan menggunakan sistem hidroponik. Jurnal Universitas Tulungagung BONOROWO, 1(2), 4350.

Setiadi, A. (2015). Studi pengelolaan sampah berbasis komunitas pada kawasan permukiman perkotaan di Yogyakarta. JURNAL WILAYAH DAN LINGKUNGAN, 3(1), 27-38.

Syawaluddin, W., \& Harahap, I. S. (2016). Pengaruh perbandingan jenis larutan hidroponik dan media tanam terhadap pertumbuhan serta hasil produksi tanaman sawi (Brassica juncea L.) driff irrigation system. Jurnal Agrohita, 1(1), 38-53. 
Tchobanoglous. G et al., (1993). Integrated solid waste management, Singapore: McGraw-Hill.

Tallei, E. Trina et al., (2017). Hidroponik untuk pemula. Manado: Lembaga Penelitian dan Pengabdian Kepada Masyarakat Universitas Sam Ratulangi.
Wasliyah, N. (2019). Budidaya sayuran menggunakan teknik hidroponik dengan botol bekas bagi anak tunarungu. Banyumas: Omera Pustaka. 